\title{
Influence of Contraception on Basic Vaginal States: A Prospective Study
}

\author{
Sonia Elena Fosch ${ }^{*}$, Cristian Yones ${ }^{2}$, Marta Trossero1, Omar Grosso1, Beatriz Perazzi ${ }^{3}$ \\ ${ }^{1}$ Servicio de Atención Médica, Ministerio de Salud, Sa Pereira, Argentina \\ ${ }^{2}$ Facultad de Ingeniería y Ciencias Hídricas, Universidad Nacional del Litoral, Santa Fe, Argentina \\ ${ }^{3}$ Departamento de Bioquímica Clínica, Hospital de Clínicas, Facultad de Farmacia y Bioquímica, Universidad de \\ Buenos Aires, Buenos Aires, Argentina \\ Email: ${ }^{*}$ sonialab1@gmail.com
}

Received 21 January 2015; accepted 13 February 2015; published 16 February 2015

Copyright (C) 2015 by authors and Scientific Research Publishing Inc.

This work is licensed under the Creative Commons Attribution International License (CC BY). http://creativecommons.org/licenses/by/4.0/

(c) $\underset{\mathrm{EY}}{\mathrm{B}}$ Open Access

\section{Abstract}

To evaluate the influence of contraceptive methods on the basic vaginal states (BVSs) in women in fertile age, 108 women consulting for birth control (14 - 45 years) were included in a prospective study. The vaginal content was sampled both before they began using the chosen contraceptive method (see below) and three months later, and then analyzed using the Balance of Vaginal Content (BAVACO) methodology. Five BVSs were defined: 1) normal microbiota; 2) normal microbiota with vaginal inflammatory reaction (VIR); 3) intermediate microbiota; 4) bacterial vaginosis and 5) non-specific microbial vaginitis. The following contraceptive methods were considered: combined oral contraceptive pill (COCP), intrauterine device (IUD), condom (CON), the rhythm method (RHYT) and simultaneous double protection (COCP + CON). The McNemar statistical test was used. COCP $(n=71): 20$ samples retained normal BVSs and two were altered; nine out of the 49 altered samples returned to normal; IUD $(n=4)$ : two samples modified their normal BVS to III and IV; CON $(n=25)$ : the VIR increased in $20 \%$ of the samples; RHYT $(n=6)$ : four samples retained the normal BVS; and COCP + CON $(n=2)$ : samples preserved their initial BVS (II). The increased frequency of BVS I in the COCP group was significant $\left(x^{2}=3.3 ; p=0.04\right)$. The relative frequency of each BVS was significantly modified, attributed to the type of contraceptive method used. The intake of hormones corrects alterations and retains a normal BVS. The contraceptive methods that use an external factor of local contact either maintain or alter the microbiota and VIR.

\section{Keywords}

Contraception, Basic Vaginal States, Vaginal Content

\footnotetext{
${ }^{*}$ Corresponding author.
} 


\section{Introduction}

The dynamic nature of the vaginal microbiota (VM) depends on the woman's age. At the first week of life the vaginal microbiota is dominated by lactobacilli. After that and until the menarche the vaginal microbiota is characterized by the presence of intermediate microbiota corresponding to intestinal and skin bacteria. At puberty, as a result of estrogenic maturation, the normal vaginal microbiota is dominated by more than 18 species of lactobacilli and, to a lesser extent, by a great variety of aerobic and anaerobic bacteria, and even yeast. It is then permissible to recognize the influence of hormonal stimulation, mainly of estrogenic origin, on vaginal colonization, and a predominance of lactobacilli in the fertile age [1]. In menopause, this microbiota becomes altered again, resembling that of the prepubescent stage, with predominance of gram-negative bacilli [1]. It is noteworthy that, in this period, the decrease in lactobacilli is not a condition for the increase in the typical anaerobic microbiota of bacterial vaginosis (BV) that occurs in fertile age.

The origin of vaginal dysfunction may respond to systemic etiologic factors or external factors such as infections and the influence of contraceptives. The clinical concept of vaginal dysfunction (VD) includes a large number of syndromes, and it has been reported that $68 \%$ of asymptomatic women in fertile age show an abnormal state of the vaginal content, which reveals the dysfunction of the vagina [2].

VD of microbial origin can be expressed in any of its individual syndromes, such as vaginitis or cases of vaginitis associated with vaginosis. It should be pointed out that vaginosis is a syndrome in which no unique infectious etiology has yet been determined. Altogether, these syndromes imply a high risk factor for the acquisition of sexually transmitted infections and maternal and perinatal complications, as well as higher surgical risk [3] [4].

Previous studies have shown differences in the frequencies of the syndromes of VD depending on the type of contraception used, such as combined oral contraceptives, intrauterine device, condom, natural methods or double protection by contraceptives and barrier [2] [5]-[8]. To date, no studies have evaluated a hormonal influence or the mechanism by which hormonal contraception can produce a protective effect against BV. Thus, we believe that this relationship requires further investigation.

The aim of this study was to evaluate the influence of the contraceptive method used on the basic vaginal states (BVSs), in women in fertile age from a socially uniform community, with similar educational and economic profiles, consulting for birth control in a Primary Health Care Center.

\section{Materials and Methods}

\subsection{Study Population and Samples}

The study included 108 women aged 14 to 45 (mean 29 years), who consulting for birth control at a Public Health Center in Sa Pereira (Santa Fe, Argentina). The study was approved by the Ethics Committee of the Hospital de Clínicas (Buenos Aires, Argentina). All women in this study gave their informed consent to participate. Each of them had their respective clinical histories, where data related to current clinical aspects were reported. A sample of the vaginal content was taken on two occasions: at the beginning of use of the contraceptive method chosen by own decision and three months later.

The analysis of the database revealed a high degree of homogeneity in the women's age, status of the couple relation and socio-economic levels, which affected no significant associations with the results observed.

Inclusion criteria: women aged 14 to 45 who accepted to participate in the study, including the gynecological examination and the collection of samples for laboratory analysis.

Exclusion criteria: women with local or systemic treatment with antibiotics, antifungals, corticosteroids, antiparasitic drugs or immunosuppressants, and women with some degree of mental disability that prevented them from giving their informed consent.

\subsection{Study Type and Design}

The study was prospective, consecutive, experimental, prevalence cross-sectional and descriptive. The study assessed the overall health status of a group of women who consulted a gynecologist to decide on the use of a contraceptive method. At the beginning of use of the method chosen, their vaginal contents were studied and the BVS established according to the Balance of Vaginal Content (BAVACO) methodology [9]. Their vaginal contents were studied again three months later and the BVS established. The evolution of the BVS was analyzed 
depending on the type of contraception used, in all the women that met the inclusion criteria.

\subsection{Study of the Vaginal Content}

The vaginal content was studied following the standardized BAVACO methodology [9]. This methodology includes the morphological analysis of the vaginal content based on the relationship of the numerical value (NV) using Nugent's method and the vaginal inflammatory reaction (VIR). Five BVSs were defined: normal microbiota (I), normal microbiota plus inflammatory reaction (II), intermediate microbiota (III), bacterial vaginosis (IV) and non-specific microbial vaginitis (V) (Table 1). The frequency of each BVS was studied based on the contraceptive method (Table 2) and the relative frequencies of yeast and trichomonas associated with each BVS was evaluated according to the contraceptive method used.

\subsection{Contraceptive Methods}

The following contraceptive methods, used without disruption for three months, were included in the study: combined oral contraceptive pill (COCP) (levonorgestrel-ethinyl estradiol), intrauterine device (IUD) with copper, condom, rhythm method and double protection (oral contraception and condom).

\subsection{Statistical Method}

For the analysis of the evolution of the frequency of the BVSs in the COCP group, the McNemar test was used.

Table 1. Criteria for the definition of the basic vaginal states (BVSs).

\begin{tabular}{|c|c|c|}
\hline BVSs in women in fertile age & NV & VIR \\
\hline $\begin{array}{l}\text { I normal microbiota } \\
\text { Predominance of lactobacilli }\end{array}$ & 0 to 3 & No \\
\hline $\begin{array}{l}\text { II normal microbiota + vaginal inflammatory reaction } \\
\text { Predominance of lactobacilli, but presence of vaginal inflammatory reaction }\end{array}$ & 0 to 3 & Yes \\
\hline $\begin{array}{l}\text { III intermediate microbiota } \\
\text { Balance between lactobacilli and anaerobic bacteria }\end{array}$ & 4 to 6 & No \\
\hline $\begin{array}{l}\text { IV bacterial vaginosis } \\
\text { Predominance of anaerobic bacteria }\end{array}$ & 7 to 10 & No \\
\hline $\begin{array}{l}\text { V non-specific microbial vaginitis } \\
\text { Alteration of the lactobacilli/anaerobic bacteria relation, with inflammatory reaction }\end{array}$ & 4 to 10 & Yes \\
\hline
\end{tabular}

BVSs: basic vaginal states; NV: numerical value; VIR: vaginal inflammatory reaction.

Table 2. Distribution of the basic vaginal states (BVSs) according to the contraception method used.

\begin{tabular}{|c|c|c|c|c|c|c|c|c|c|c|}
\hline \multirow{3}{*}{ BVS } & \multicolumn{2}{|c|}{$\mathrm{COCP}^{1}$} & \multicolumn{2}{|c|}{ IUD $^{2}$} & \multicolumn{2}{|c|}{$\mathrm{CON}^{3}$} & \multicolumn{2}{|c|}{ RYTH $^{4}$} & \multicolumn{2}{|c|}{$\mathrm{COCP}+\mathrm{CON}^{5}$} \\
\hline & \multirow{2}{*}{$\begin{array}{c}\text { before } \\
\mathrm{N}\end{array}$} & 3 months & \multirow{2}{*}{$\begin{array}{c}\text { before } \\
\mathrm{N}\end{array}$} & 3 months & \multirow{2}{*}{$\begin{array}{c}\text { before } \\
\mathrm{N}\end{array}$} & 3 months & \multirow{2}{*}{$\begin{array}{c}\text { befor } \\
\text { e } \\
\mathrm{N}\end{array}$} & 3 months & \multirow{2}{*}{$\begin{array}{l}\text { before } \\
\mathrm{N}\end{array}$} & \multirow{2}{*}{$\begin{array}{c}3 \text { months } \\
\text { BVS (n) }\end{array}$} \\
\hline & & BVS (n) & & BVS (n) & & BVS (n) & & BVS (n) & & \\
\hline I & 22 & $\mathrm{I}(20)$ - II(2) & 3 & $\begin{array}{c}\mathrm{I}(1)-\mathrm{III}(1) \\
\mathrm{IV}(1)\end{array}$ & 4 & I(1) - II(3) & 4 & $\mathrm{I}(4)$ & - & - \\
\hline II & 20 & $\begin{array}{c}\mathrm{I}(1)-\mathrm{II}(16)- \\
\mathrm{III}(3)\end{array}$ & 1 & II(1) & 7 & $\mathrm{I}(1)-\mathrm{II}(6)$ & 1 & II(1) & 2 & $\mathrm{II}(2)$ \\
\hline III & 4 & $\begin{array}{l}\mathrm{I}(1)-\mathrm{II}(1) \\
\quad \mathrm{III}(2)\end{array}$ & . & - & - & - & - & - & - & - \\
\hline IV & 13 & $\begin{array}{l}\mathrm{I}(5)-\mathrm{II}(1) \\
\quad \mathrm{IV}(7)\end{array}$ & - & - & 10 & $\begin{array}{c}\mathrm{I}(1) \text { - II(1) } \\
\mathrm{IV}(7) \text { - V(1) }\end{array}$ & 1 & IV(1) & - & - \\
\hline $\mathbf{V}$ & 12 & $\begin{array}{c}\mathrm{I}(2)-\mathrm{II}(3) \\
\mathrm{IV}(2)-\mathrm{V}(5)\end{array}$ & - & - & 4 & IV(1) - V(3) & - & - & - & - \\
\hline total & 71 & & 4 & & 25 & & 6 & & 2 & \\
\hline
\end{tabular}

COCP: combined oral contraceptive pill (levonorgestrel-ethinylestradiol); IUD: intrauterine device; CON: condom; RYTH: rhythm method; COCP + CON: double simultaneous protection. 
A $P$ value $<0.05$ was considered statistically significant. InfoStat-2009 version (National University of Cordoba, Argentina) was the software used.

\section{Results}

In the first evaluation, prior to the beginning of use of the contraceptive method chosen, out of the 108 women included in the study: 33 (30.6\%) showed BVS I, 31 (28.7\%) showed BVS II, 4 (3.7\%) showed BVS III, 24 (22.2\%) showed BVS IV and 16 (14.8\%) showed BVS V. The distribution of the BVSs according to the contraceptive method chosen, at the beginning of its use and after three months of use, is shown in Table 2. In the COCP group $(n=71), 20$ patients retained BVS I, 2 were altered and 9 out of the 49 patients that showed altered BVSs at the beginning of use of COCP, returned to BVS I after three months. These changes showed statistically significant association with BVS I $\left(X^{2}=3.3 ; \mathrm{p}<0.04\right)$. When we considered only the changes in the vaginal microbiota, independent of the variation in the VIR, we found that 39 patients retained the BVS with normal vaginal microbiota, 3 cases with initial normal vaginal microbiota were altered, and out of 29 women with vaginal dysfunction before the start of the use of COCP, 13 returned to normal vaginal microbiota, These results showed statistically significant association with normal vaginal microbiota $\left(X^{2}=5.06 ; p<0.01\right)$.

Of the four women who chose IUD, two had their BVS modified to intermediate microbiota in one case (BVS III) and in another bacterial vaginosis (BVS IV) (Table 2).

Out of the 25 women who chose the use of condom, five (20\%) showed an increase in the VIR, two (8\%) returned to BVS I and the remaining retained altered BVSs (Table 2).

The six patients who chose the rhythm method retained their initial BVSs: four retained BVS I, one BVS II and the another one BVS IV. Women who chose the double protection (COCP + CON) retained BVS II (Table 2).

Before the use of COCP, we detected yeasts in 26 samples, seven with BVS I, eleven with BVS II, one with BVS III, three with BVS IV and four with BVS V, whereas three months later, twelve had BVS I, nine had BVS II, two had BVS III, two had BVS IV and two had BVS V. It should be noted that only six symptomatic women with initial BVS II (4) and V (2) were treated with antifungals (Table 3).

Before the use of IUD, we detected yeasts in an asymptomatic woman with BVS II whose vaginal content remained the same after three months (Table 3).

Before the use of condom, we found yeasts in nine women: four with BVS II, three with BVS IV and two with BVS V, whereas three months later three had BVS II, two had BVS V and one had BVS IV. Only symptomatic women with BVS II (1) and V (1) were treated (Table 3).

Before the use of the rhythm method, we found yeasts in one woman with BVS I, who retained the same after three months.

In the COCP and CON group, we detected yeasts in one patient with BVS II belonging to an asymptomatic woman and after three months the two patients of this group showed yeasts in the same BVS II (Table 3).

Trichomonas were detected in 7 out of the 108 women included at the begining of the study. Six corresponded

Table 3. Distribution of yeasts associated with the basic vaginal states (BVSs) according to the contraceptive method used.

\begin{tabular}{|c|c|c|c|c|c|c|c|c|c|c|}
\hline \multirow{2}{*}{ BVS } & \multicolumn{2}{|c|}{$\mathrm{COCP}^{1}$} & \multicolumn{2}{|c|}{$\mathrm{IUD}^{2}$} & \multicolumn{2}{|c|}{$\mathrm{CON}^{3}$} & \multicolumn{2}{|c|}{$\mathrm{RYTH}^{4}$} & \multicolumn{2}{|c|}{$\mathrm{COCP}+\mathrm{CON}^{5}$} \\
\hline & $\begin{array}{l}\text { before } \\
\mathrm{N}\end{array}$ & $\begin{array}{l}3 \text { months } \\
\text { BVS (n) }\end{array}$ & $\begin{array}{l}\text { before } \\
\mathrm{N}\end{array}$ & $\begin{array}{l}3 \text { months } \\
\text { BVS (n) }\end{array}$ & $\begin{array}{c}\text { before } \\
\mathrm{N}\end{array}$ & $\begin{array}{l}3 \text { months } \\
\text { BVS (n) }\end{array}$ & $\begin{array}{c}\text { before } \\
\mathrm{N}\end{array}$ & $\begin{array}{l}3 \text { months } \\
\text { BVS (n) }\end{array}$ & $\begin{array}{c}\text { before } \\
\mathrm{N}\end{array}$ & $\begin{array}{l}3 \text { months } \\
\text { BVS (n) }\end{array}$ \\
\hline I & 7 & 12 & - & - & - & - & 1 & 1 & - & - \\
\hline II & $\begin{array}{c}11 \\
(4 / 11)^{*}\end{array}$ & 9 & 1 & 1 & $\begin{array}{c}4 \\
(1 / 4)^{*}\end{array}$ & 3 & - & - & 1 & 2 \\
\hline III & 1 & 2 & - & - & - & - & - & - & - & - \\
\hline IV & 3 & 2 & - & - & 3 & 1 & - & - & - & - \\
\hline V & $\begin{array}{c}4 \\
(2 / 4)^{*}\end{array}$ & 2 & - & - & $\stackrel{2}{2}(1 / 2)^{*}$ & 2 & - & - & - & - \\
\hline total & 26 & 27 & 1 & 1 & 9 & 6 & 1 & 1 & 1 & 2 \\
\hline
\end{tabular}

COCP: combined oral contraceptive pill (levonorgestrel-ethinylestradiol); IUD: intrauterine device; CON: condom; RYTH: rhythm method; COCP + CON: double simultaneous protection; ${ }^{*}$ symptomatic with antifungal treatment. 
to women who consulted for the use of COCP, who had BVS V. After treatment (metronidazole $1000 \mathrm{mg}$ daily for 7 days) and after three months of use of COCP, we found absence of the parasite in five samples: three with BVS II, one with BVS IV and one with BVS V. Persistence of the parasite with BVS V was detected in the remaining sample (Table 4). The other sample with trichomonas corresponded to a woman who consulted for the use of the rhythm method, who had BVS V associated with atypical cells, This result determined the medical decision of referral to a Health Center of greater complexity, where she was diagnosed with uterine cancer (Table 4).

\section{Discussion}

The most accepted hypothesis is that the balance of the microbiota of the vaginal content of women in fertile age is primarily established by hormonal mechanisms, mainly due to the "estrogen effect". According to the results of this research, the use of COCP associated to retain normal microbiota and was able to decrease the frequency of bacterial vaginosis. This may be due to the hormonal contribution of COCP, which, although it is an "external" factor, it represents direct regulator of the hormonal mechanism and, therefore, emphasizes the hypothesis of the estrogen effect on the frequency of vaginal dysfunction. Similar results were described in a few recent studies which have reported only the effect of hormones [5]-[7]. Vodstrcil et al. mentioned the protective influence of exogenous steroid hormones on the vaginal content [5]. These authors described that more than $50 \%$ of women with recurrent bacterial vaginosis in spite of receiving treatment with first-line antibiotics showed a significant improvement in the recurrence of this vaginal dysfunction upon receiving hormonal contraception [5]. It should be noted that this mechanism of protection, which has been shown both for endogenous and exogenous sex hormones, perform its effect on the vaginal mucosa through the cell receptors. These receptors stimulate the multiplication of the epithelium and thus ensure a good concentration of glycogen in intermediate cells, allowing the survival of lactobacilli and maintenance of a protective $\mathrm{pH}$ [10]. Estrogen stimulation produces a predominance of cells of the surface layer, whereas progesterone stimulation produces a predominance of cells of the intermediate layer [11]. This determines the lysis of the latter, which generates glycogen and nourishes lactobacilli [12] [13]. In addition, recent studies have documented an important activity of proton pumping (by an $\mathrm{H}^{+}$-ATPase) in the apical membrane of the cells of the vaginal and cervical epithelium stimulated by estrogen, which decreases at menopause with the consequent increase in vaginal $\mathrm{pH}$ [14]. However, it should be highlighted, according to the results of this research, the use of COCP predisposed the colonization by yeasts in healthy women, since after three months we detected an increase in the vaginal content with yeasts but with BVS I, as described by other authors [2] [6] [7]. However, it cannot be ruled out that this colonization represents a predisposing factor for recurrent vulvo-vaginitis.

In this study, we observed that patients who used IUD showed a tendency to have an imbalanced vaginal microbiota. However, it is necessary to increase the number of cases to confirm these findings, since the use of IUD is an effective method in conditions where other contraceptives may not be used (e.g. smoking, migraine,

Table 4. Distribution of trichomonas associated with the basic vaginal states (BVSs) according to the contraceptive method used.

\begin{tabular}{|c|c|c|c|c|c|c|c|c|c|c|}
\hline \multirow{2}{*}{ BVS } & \multicolumn{2}{|c|}{$\mathrm{COCP}^{1}$} & \multicolumn{2}{|c|}{$\mathrm{IUD}^{2}$} & \multicolumn{2}{|c|}{$\mathrm{CON}^{3}$} & \multicolumn{2}{|c|}{$\mathrm{RYTH}^{4}$} & \multicolumn{2}{|c|}{$\mathrm{COCP}+\mathrm{CON}^{5}$} \\
\hline & $\begin{array}{c}\text { before } \\
\mathrm{N}\end{array}$ & $\begin{array}{l}3 \text { months } \\
\text { BVS (n) }\end{array}$ & $\begin{array}{c}\text { before } \\
\mathrm{N}\end{array}$ & $\begin{array}{l}3 \text { months } \\
\text { BVS (n) }\end{array}$ & $\begin{array}{l}\text { before } \\
\mathrm{N}\end{array}$ & $\begin{array}{l}3 \text { months } \\
\text { BVS (n) }\end{array}$ & $\begin{array}{c}\text { before } \\
\mathrm{N}\end{array}$ & $\begin{array}{l}3 \text { months } \\
\text { BVS (n) }\end{array}$ & $\begin{array}{c}\text { before } \\
\mathrm{N}\end{array}$ & $\begin{array}{l}3 \text { months } \\
\text { BVS (n) }\end{array}$ \\
\hline I & - & - & - & - & - & - & - & - & - & - \\
\hline II & - & 3 & - & - & - & - & - & - & - & - \\
\hline III & - & - & - & - & - & - & - & - & - & - \\
\hline IV & - & 1 & - & - & - & - & - & - & - & - \\
\hline $\mathrm{V}$ & 6 & $\begin{array}{c}2 \\
(1 / 2)^{*}\end{array}$ & - & - & - & - & $1^{* *}$ & - & - & - \\
\hline total & 6 & - & - & - & - & - & 1 & - & - & - \\
\hline
\end{tabular}

COCP: combined oral contraceptive (levonorgestrel-ethinylestradiol); IUD: intrauterine device; CON: condom; RYTH: rhythm method; COCP + CON: double simultaneous protection; ${ }^{*}$ Persistence of the parasite; ${ }^{* * *}$ Patient excluded from the study. 
thrombosis, hypertension, etc.). Gupta et al. described similar findings and reported that barrier methods alter the vaginal content since they represent a foreign body for long periods of time [6]. However, there is still no accurate explanation of their effect on the vaginal microbiota. Tessa Madden et al. showed that the incidence of bacterial vaginosis is higher in IUD users than in women using other methods and detected a positive association with two mediators: the irregular vaginal bleeding and an intermediate vaginal microbiota (BVS III) present at implantation of the device [15].

In this study, the use of male condoms, a method chosen mainly by the security offered both contraception and sexually transmitted infections, was associated with an increase in the vaginal content with VIR. These results are consistent with previous reports that have shown the presence of vaginal dermatitis, allergic and irritant vulvo-vaginitis and inflammation associated with the use of condoms, due to the influence of either the latex or the spermicides (nonoxynol-9) [16]. A non-keratinized vulvar mucosa and the moisture in which it is immersed predispose the penetration of irritants and allergens, which generates states of vaginitis with VIR [17] [18].

Finally, we cannot conclude about the influence of the rhythm method and double protection on the BVSs due to the low number of cases. The rhythm method, which is based on the recognition of the signs and symptoms associated with physiological fertility and infertility periods and the use of the infertile periods for sexual activity, is currently one of the least chosen methods. There is thus few knowledge about its influence on the vaginal microbiota.

\section{Conclusion}

Considering similar characteristics of the population of this study, we conclude that the use of COCP as a contraceptive method retains the normal BVS I and corrects the vaginal dysfunction. These results indicate that it is necesary to continue this study with a greater number of cases to confirm the imbalance of the microbiota and the inflammatory reaction detected with the use of IUD and condom respectively.

\section{References}

[1] Reid, G., McGroarty, J.A., Tomeczek, L. and Bruce, A.W. (1996) Identification and Plasmid Profiles of Lactobacillus Species from the Vagina of 100 Healthy Women. FEMS Immunology and Medical Microbiology, 15, 23-26. http://dx.doi.org/10.1111/j.1574-695X.1996.tb00354.x

[2] Fosch, S., Yones, C., Trossero, M. and Grosso, O. (2013) The Influence of Different Contraceptive Methods on Vaginal Microbiota: Clinical Study. Health, 5, 19-24. http://dx.doi.org/10.4236/health.2013.57A4003

[3] Andrews, W., Hauth, J., Cliver, S., Conner, M., Goldenberg, R. and Goepfert, A. (2006) Association of Asymptomatic Bacterial Vaginosis with Endometrial Microbial Colonization and Plasma Cell Endometritis in Non Pregnant Women. American Journal of Obstetrics and Gynecology, 195, 1611-1616. http://dx.doi.org/10.1016/j.ajog.2006.04.010

[4] MGregor, J.A. (2000) French J. L. Bacterial Vaginosis in Pregnancy. Obstetrical \& Gynecological Survey, 55, 1-19. http://dx.doi.org/10.1097/00006254-200005001-00001

[5] Vodstrcil, L.A., Hocking, J.S., Law, M., Walker, S., Tabrizi, S.N., et al. (2013) Hormonal Contraception Is Associated with a Reduced Risk of Bacterial Vaginosis: A Systematic Review and Meta-Analysis. PloS ONE, 8, e73055. http://dx.doi.org/10.1371/journal.pone.0073055

[6] Gupta, K., Hillier, S.L., Hooton, T.M., Roberts, P.L. and Stamm, W.E. (2000) Effects of Contraceptive Method on the Vaginal Microbialflora: A Prospective Evaluation. The Journal of Infectious Diseases, 181, 595-601. http://dx.doi.org/10.1086/315267

[7] Tibaldi, C., Capello, N., Latino, M., Masuelli, G., Marini, S. and Benedetto, C. (2009) Vaginal and Endocervical Microorganisms in Symptomatic and Asymptomatic Non-Pregnant Females: Risk Factors and Rates of Occurrence. Clinical Microbiology and Infection, 15, 670-679. http://dx.doi.org/10.1111/j.1469-0691.2009.02842.x

[8] Riggs, M., Klebanoff, M., Nansel, T., Zhang, J., Schwebke, J. and Andrews, W. (2007) Longitudinal Association between Hormonal Contraceptives and Bacterial Vaginosis in Women of Reproductive Age. Sexually Transmitted Diseases, 34, 954-959.

[9] (2010) Guía Práctica Integral (Clínica-Laboratorio) de diagnóstico de vaginosis y vaginitis en la atención primaria de la (MEF). Actualización 2010. Acta Bioquímica Clínica Latinoamericana, 44, 359-369.

[10] Hans, F.N. (2004) Citodiagnóstico Ginecológico. $1^{\circ}$ Edición, Buenos Aires Médica Paramericana 2004.

[11] Levin, R.J. (2004) Measuring Female Genital Functions-A Research Essential but still a Clinical Luxury? Sexual and 
Relationship Therapy, 19, 191-200. http://dx.doi.org/10.1080/14681990410001691406

[12] Huggyns, G.R. and Preti, G. (1981) Vaginal Odors and Secretions. Clinical Obstetrics and Gynecology, 24, 355-377. http://dx.doi.org/10.1097/00003081-198106000-00005

[13] Boskey, E.R., Cone, R.A., Whaley, K.J. and Moench, T.R. (2001) Origins of Vaginal Acidity: High D/L Lactate Ratio Is Consistent with Bacteria Being the Primary Source. Human Reproduction, 16, 1809-1813. http://dx.doi.org/10.1093/humrep/16.9.1809

[14] Gorodeski, G.I., Hopfer, U., Liu, C.C. and Margles, E. (2005) Estrogen Acidifies Vaginal pH by Up-Regulation of Proton Secretion via the Apical Membrane of Vaginal-Ectocervical Epithelial Cells. Endocrinology, 146, 816-824. http://dx.doi.org/10.1210/en.2004-1153

[15] Madden, T., Grentzer, J.M., Secura, G.M., Allsworth, J.E. and Peipert, J.F. (2012) Risk of Bacterial Vaginosis in Users of the Intrauterine Device: A Longitudinal Study. Sexually Transmitted Diseases, 39, 217-222.

[16] Schreiber, C.A., Meyn, L.A., Creinin, M.D., Barnhart, K.T. and Hillier, S.L. (2006) Effects of Long-Term Use of Nonoxynol-9 on Vaginal Flora. Obstetrics \& Gynecology, 107, 136-143. http://dx.doi.org/10.1097/01.AOG.0000189094.21099.4a

[17] Moraes, P.S. and Taketomi, E.A. (2000) Allergic Vulvovaginitis. Annals of Allergy, Asthma Immunology, 85, $253-265$. http://dx.doi.org/10.1016/S1081-1206(10)62527-6

[18] Ramirez de Knott, H.M., McCormick, T.S., Oshtory Do, S., Goodman, W., Ghannoum, M.A., Cooper, K.D. and Nedorost, S.T. (2005) Cutaneous Hypersensitivity to Candida albicans in Idiopathic Vulvodynia. Contact Dermatitis, 53, 214-218. http://dx.doi.org/10.1111/j.0105-1873.2005.00685.x 
Scientific Research Publishing (SCIRP) is one of the largest Open Access journal publishers. It is currently publishing more than 200 open access, online, peer-reviewed journals covering a wide range of academic disciplines. SCIRP serves the worldwide academic communities and contributes to the progress and application of science with its publication.

Other selected journals from SCIRP are listed as below. Submit your manuscript to us via either submit@scirp.org or Online Submission Portal.
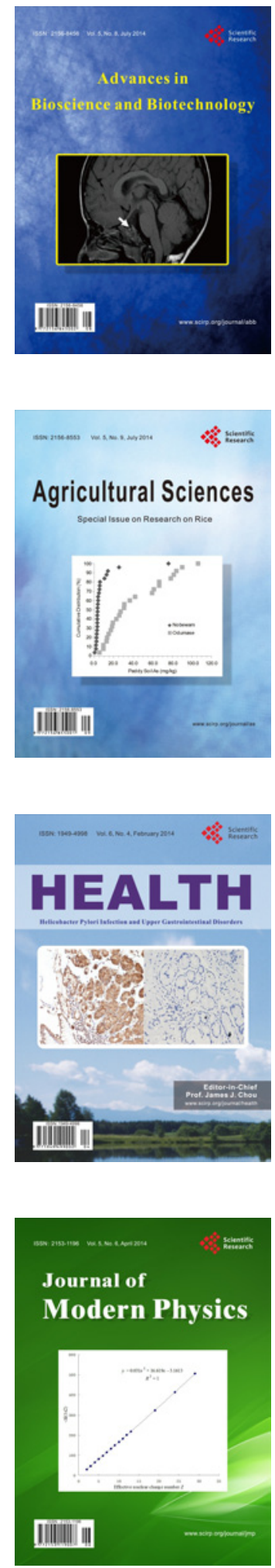
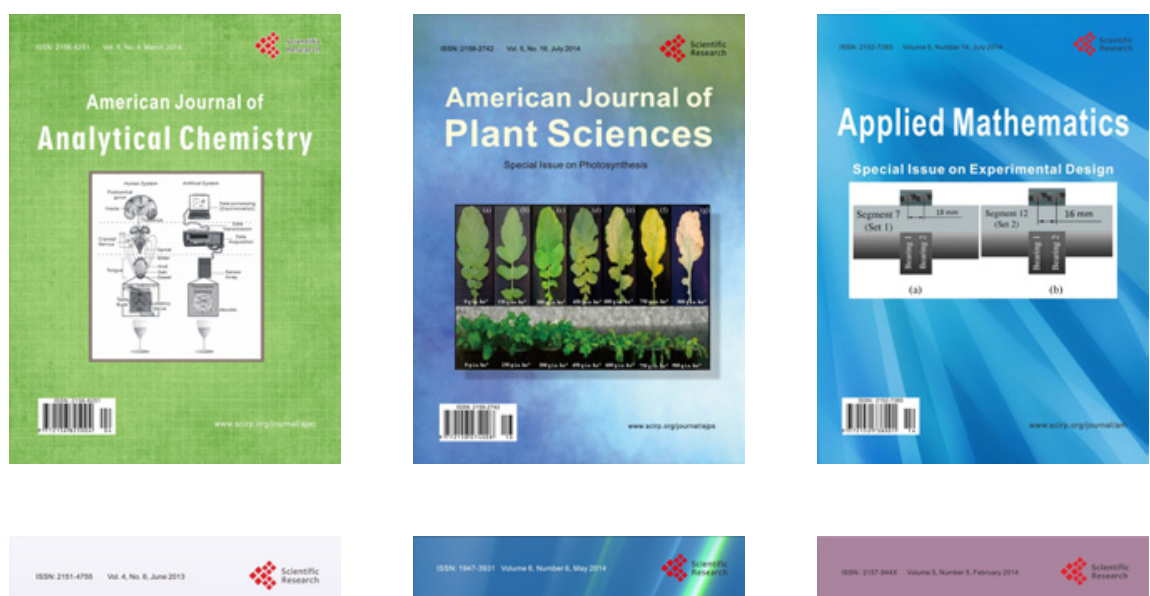

Creative Education
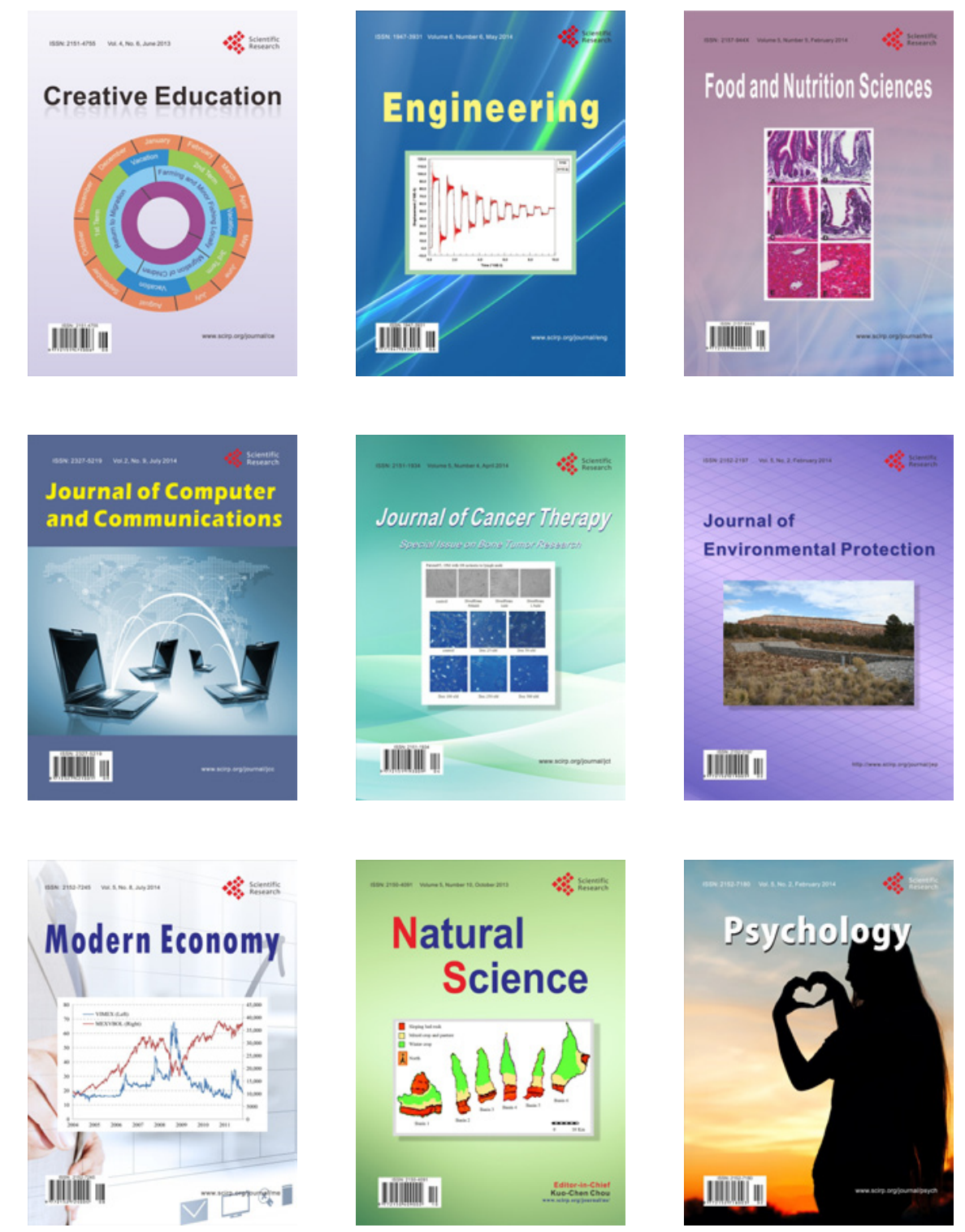